\title{
Parker v. Brown: A Preemption Analysis
}

The Sherman Act ${ }^{1}$ by its terms forbids "every contract, combination ... or conspiracy, in restraint of trade or commerce among the several states ...."2 Although Congress has exempted from the statute particular segments of the business community, ${ }^{3}$ the Act generally ensures that competition, as the guiding principle in economic affairs, ${ }^{4}$ will remain the national policy. ${ }^{5}$

In Parker v. Brown, ${ }^{6}$ the Supreme Court excepted a state agricultural proration program from the reach of the Sherman Act. Although the Supremacy Clause ${ }^{7}$ generally gives effect to federal policy over conflicting state policy, the Parker doctrine recognizes the state policy instead. ${ }^{8}$ The apparent anomaly of Parker has caused considerable

1. Act of July 2, 1890, ch. 647,26 Stat. 209, as amended, 15 U.S.C. $\$ \$ 1-7$ (1970).

2. Id. $\S 1$. This language has been interpreted to forbid only "unreasonable restraints." Standard Oil Co. v. United States, 221 U.S. 1 (1911). This interpretation, the "rule of reason," refers to the "common law" or case-by-case process of defining rules carried on by the courts in antitrust cases.

It is not possible to define precisely a "reasonable" restraint. Some restraints are per se unreasonable, e.g., horizontal price fixing. United States v. Socony-Vacuum Oil Co., 310 U.S. 150 (1940); United States v. Container Corp. of Am., 393 U.S. 333 (1969). Other restraints are unreasonable only in so far as their market effects are such as to suppress or destroy competition. White Motor Co. v. United States, 372 U.S. 253 (1963). See generally Atr'y Gen.'s Nat'l Comm. to Study the Antitrust Laws, Report (1955) [hereinafter cited as REPORT].

3. The congressional exemption may take one of two forms. The exemption may allow specific groups to organize. See, e.g., Clayton Act $\$ 6$, ch. 25, $\$ 6,38$ Stat. 731 (1914), as amended, 15 U.S.C. $\$ 17$ (1970); Capper-Volstead Act $\$ 1,7$ U.S.C. $\$ \$ 291-92$ (1970).

These exemptions have been interpreted by the courts to allow only the legitimate ends of organizing per se. If the organized group then contracts, combines or conspires with nonexempt persons or groups, they will be liable for a violation of the antitrust laws. E.g., UMW v. Pennington, 381 U.S. 65' (1965); Maryland \& Virginia Milk Producers Ass'n v. United States, 362 U.S. 458 (1960); Allen-Bradley Co. v. Local 3, IBEW, 325 U.S. 797, 809 (1945); United States v. Borden Co., 308 U.S. 188 (1939); cf. Case-Swayne Co. v. Sunkist Growers, Inc., 389 U.S. 384 (196\%).

The second form is an exemption under specified circumstances for regulated industries. For example, the statute establishing a regulatory agency may allow the agency, after public hearings and specified findings, to approve actions (e.g., mergers) which would otherwise be violations of the antitrust laws. E.g., Interstate Commerce Act, 49 U.S.C. $\$ \$$ 5(1), 5(11), 5b (1970); Federal Aviation Act, 49 U.S.C. $\$ \$ 1302,1378$ (1970). In other cases, Congress has specified that the antitrust laws are applicable only in so far as the industry is not subject to regulation by the state. E.g., McCarran-Ferguson Act, 15 U.S.C. $\$ \$ 1012-13$ (1970) (insurance); Fair Trade Act, 15 U.S.C. \$ 1 (1970).

4. Northern Pac. Ry. v. United States, 356 U.S. 1, 4 (1958).

5. See United States v. Yellow Cab Co., 332 U.S. 218 (1947).

6. 317 U.S. 341 (1943).

7. U.S. Const. art. VI, cl. 2.

8. In this Note, the "Parker doctrine" refers only to those instances where a state policy is challenged under the federal antitrust laws. Although Parker is often cited, cases dealing with the relationship betwcen federal agencies and the federal antitrust statutes present a different issue. Congress may change or limit its own policies without raising federalism or Supremacy Clause issues. See Hecht v. Pro-Football, Inc., 44 F.2d 931 (D.C. Cir. 1971), cert. denied, 404 U.S. 1047 (1972). In federal regulatory cases the issue is one of primary jurisdiction and deference to agency findings. Otter Tail Power 
confusion among courts and commentators, and the Court has as yet failed to provide clear standards for the application of the doctrine. ${ }^{9}$

This Note will examine the Parker doctrine by means of a preemption analysis under the Supremacy Clause. The facts and opinion in Parker itself will first be presented. A general framework for preemption analysis will then be developed and applied to the federal antitrust laws. Finally, after a criticism of the traditional "state action" interpretation, the Parker defense will be explained in terms of the suggested preemption analysis.

\section{The Parker Case}

The California Raisin Proration Program, implemented under the State Agricultural Proration Act, was designed to stabilize the market in raisins and to maintain prices during a period of economic crisis. Brown, a producer-dealer, had sold short on the market in 1941, believing that the price of raisins would decline from its high level as farmers were forced to dump a large crop on the market. Brown attempted to forestall the price maintenance effects of the proration program by filing suit in federal district court to enjoin enforcement of the program. A three-judge district court ruled in Brown's favor, ${ }^{10}$ but the Supreme Court unanimously reversed that decision, holding that the program did not violate the Sherman Act, ${ }^{11}$ was not preempted

Co. v. United States, 410 U.S. 366 (1973); United States v. ICC, 396 U.S. 491 (1970). In the state cases, there is the underlying constitutional issue of the distribution of power within the federal system and the authority of Congress to impose regulations on the sovereign states. These cases do not present the problem of conflicting congressional policies, but rather the more difficult issue of federal-state relations. For cases involving federal agencies and the antitrust laws, see Otter Tail Power Co. v. United States, 410 U.S. 366 (1973) (FPC); Hughes Tool Co. v. Trans World Airlines, Inc., 409 U.S. 363 (1973) (CAB); United States v. ICC, 396 U.S. 491 (1970); Denver \& R.G.W. R.R. v. United States, 387 U.S. 485 (1967) (ICC); Silver v. New York Stock Exch., 373 U.S. 341 (1963) (SEC); Pan American World Airways, Inc. v. United States, 371 U.S. 296 (1963) (CAB); California v. FPC, 369 U.S. 482 (1962); United States v. RCA, 358 U.S. 334 (1959) (FCC); Gordon v. New York Stock Exch., 498 F.2d 1303 (2d Cir. 1974) (SEC); Thill Sec. Corp. v. New York Stock Exch., 433 F.2d 264 (2d Cir. 1970), cert. denied, 401 U.S. 994 (I971) (SEG). See generally Fox, The Antitrust Laws and Regulated Industries: $A$ Reappraisal of the Role of the Primary Jurisdiction Doctrine, 2 MEM. ST. U.L. REv. 279 (1972); Petrucelli \& Long, Antitrust and the Regulated Industries: The Role of the "Doctrine" of Primary Jurisdiction, 1969 U. ToL. L. REv. 303; Stelzer, Antitrust and Regulatory Policies: An Introduction and Overview, 16 ANTITRUst BuLL. 669, 671-72 (1971); Note, Regulated Industries and the Antitrust Laws: Substantive and Procedural Coordination, 58 CoLUM. L. REv. 673 (1958).

9. An opportunity for clarification by the Court came last term in United States v. Pacific Southwest Airlines, 358 F. Supp. 1224 (C.D. Cal.), appeal dismissed pursuant to Rule 60,414 U.S. 801 (1973). The Court has continued to refuse certiorari in other cases in this field. But see Goldfarb v. Virginia State Bar, 497 F.2d I (4th Cir.), cert. granted, 95 S. Ct. 223 (1974); Slater, Antitrust and Government Action: A Formula for Narrowing Parker v. Brown, 69 Nw. U.L. Rev. 71, 74 n.13 (1974).

10. Brown v. Parker, 39 F. Supp. 895 (S.D. Cal. 1941).

11. 317 U.S. at $350-52$. 
by the Agricultural Marketing Act of 1937,12 and did not impose an undue burden on interstate commerce. ${ }^{13}$ In his Sherman Act analysis, Chief Justice Stone assumed arguendo that the proration program would have been illegal if established by private persons. ${ }^{14}$ However, the Court ruled that the Sherman Act was inapplicable to the situation presented in Parker, because Congress had never intended to restrain or regulate "state action"15:

We find nothing in the language of the Sherman Act or in its history which suggests that its purpose was to restrain a state or its officers or agents from activities directed by its legislature.

....

The state in adopting and enforcing the prorate program made no contract or agreement and entered into no conspiracy in restraint of trade or to establish a monopoly but, as sovereign, imposed a restraint as an act of government which the Sherman Act did not undertake to prohibit. ${ }^{16}$

Based on Parker, a broad antitrust defense became available if the challenged activity were at all regulated by the state. ${ }^{17}$ The lower courts, left with little specific guidance, have disagreed on the application of the Parker doctrine. ${ }^{18}$

12. Id. at 352-59.

13. Id. at $359-67$.

14. Id. at 350 . The issue of a Parker defense does not arise where the challenged governmental action would not be illegal if done by private parties. Therefore, this Note will deal only with those situations in which the federal antitrust laws would be at least arguably applicable if private parties engaged in the conduct at issue.

Where the state acts in a proprietary rather than governmental capacity, somewhat different issues are involved. Consideration of this problem is beyond the scope of this Note. But see Slater, supra note 9 , at 89 (treats the issue of the state as a proprietor as a limitation on the Parker doctrine).

15. 317 U.S. at 350-51. The Court assumed that Congress could constitutionally prohibit a state from mandating a stabilization program, but held that it had not done so in passing the Sherman Act. Id. at 350-54.

16. Id. at 350-52. See Olsen v. Smith, 195 U.S. 332, 344-45 (1904).

17. Even where there is a comprehensive scheme, however, a Parker defense will not be allowed if the regulatory decisions are based on false information given by one of the parties. See Woods Exploration \& Prod. Co. v. Aluminum Co. of Am., 438 F.2d 1286 (5th Cir. 1971), cert. denied, 404 U.S. 1047 (1972). Another important limitation on the right of the state to impose regulations is that all parties must be treated equally by the regulatory agency. See Hecht v. Pro-Football, Inc., 444 F.2d 931 (D.C. Cir. 1971), cert. denied, 404 U.S. 1047 (1972).

18. Compare Asheville Tobacco Bd. of Trade, Inc. v. FTC, 263 F.2d 502 (4th Cir. 1959), and Travelers Ins. Co. v. Bluc Cross of W. Pa., 298 F. Supp. 1109 (W.D. Pa. 1969), with Gaslight Co. v. Georgia Power Co., 440 F.2d 1135 (5th Cir. 1971), cert. denied, 404 U.S. 1062 (1972).

For an analysis which attempts to explain the cases following Parker in terms of the degree of state action involved, see Teply, Governmental Antitrust Immunity, 48 TuL. L. REV. 272 (1974). See also Donnem, Federal Antitrust Law Versus Anticompetitive State Regulations, 39 A.B.A. ANrrrrust L.J. 950, 958-60 (1970); Kirkpatrick, The State Action Antitrust Immunity Defense, 23 AM. U.L. REv. 527 (1974); Posner, The Proper Relationship Between State Regulation and the Federal Antitrust Laws, 49 N.Y.U.L. REv. 693 
Two essential issues remain to be satisfactorily resolved. The first is what degree of state action or involvement is required to establish a Parker defense. The second is an explanation of why a state should be allowed to take anticompetitive action that is foreclosed to a private party. The resolution of both issues may be found in a preemption analysis of the Sherman Act.

\section{The Doctrine of Preemption}

Preemption is a judicially created doctrine based on the Supremacy Clause of the Constitution. ${ }^{19}$ By giving primacy to federal law, it ensures that congressional policy will not be defeated by inconsistent state policies; where Congress has chosen to act, federal law will not be rendered ineffective by disagreement among the states. In this way, the doctrine of preemption historically helped to establish a federal union that would be cemented not only by trade, but also by common policies. ${ }^{20}$

The preemption analysis proceeds by a series of interrelated steps. The first step is to identify the field in which the challenged state law operates or has its effects, and to determine whether there is a federal policy or law also operating in that field. ${ }^{21}$ The determination

(1974); Simmons \& Fornaciari, State Regulation as an Antitrust Defense: An Analysis of the Parker v. Brown Doctrine, 43 U. CIN. L. Rev. 61 (1974); Slater, supra note 9; Note, Bar Association Minimum Fee Schedules and the Antitrust Laws, 1974 Duke L.J. 1164, 1211-26; Note, The Limits of State Regulation Under the McCarran-Ferguson Act, 42 Geo. Wash. L. Rev. 427 (1974); Note, Parker v. Brown-Gone to Hecht: $A$ New Test for the State Action Exemption, 24 HAST. L.J. 287 (1973); Note, Debate on State Versus Federal Regulation of Insurance Continues, 53 NeB. L. REv. 289 (1974); Note, Participant Governmental Action Immunity from the Antitrust Laws: Fact or Fiction?, 50 TExAs L. REV. 474 (1972); 19 WAYNE L. REv. 1245 (1973).

19. U.S. CoNST, art. VI, cl. 2. "This Constitution, and the Laws of the United States which shall be made in Purstance thereof; ..., shall be the supreme Law of the Land; and the Juclges in every State shall be bound thereby, any Thing in the Constitution or Laws of any State to the Contrary notwithstanding."

State regulation, of course, is open to challenge on grounds other than preemption, and often courts will deal with those grounds before reaching the preemption issue. The regulation, in order to be valid as an exercise of police power, must be related to the public health, safety, or morals, must not be unreasonable or arbitrary, and must have a rational relation to the purported evil being remedied. See Lawton v. Steele, 152 U.S. 133 (1894); Hennington v. Georgia, 163 U.S. 299 (1896).

Nor can such a regulation be a burden on interstate commerce, aside from the antitrust implications. See Pike v. Bruce Church, Inc., 397 U.S. 137 (1970); Dean Milk Co. v. Madison, 340 U.S. 349 (1951); Baldwin v. Seelig, 294 U.S. 511 (1935); Gibbons v. Ogden, 22 U.S. (9 Wheat.) 1 (1824); Flood v. Kuhn, 443 F.2d 264, 267 (2d Cir. 1971), aff'd, 407 U.S. 258 (1972).

20. See 3 J. Story, Commentaries on the Constitution $\$ \S 1839-40$, at $582-83$ (2d ed. 1873). See generally 1 J. Story, Commentaries on the Constiturion $\$ \S 228-32,248-53$, at 215-19 (2d ed. 1873); The Federalist No. 15 (A. Hamilton).

21. See Rice v. Santa Fe Elevator Corp., 331 U.S. 218 (1947); Hines v. Davidowitz, 312 U.S. 52 (1941). 
of the field of the state law and of a potentially competing federal law are both questions of law to be decided by the court. ${ }^{22}$

The next step in the analysis focuses upon the federal statute or policy. The court must decide whether the federal regulation was intended to be exclusive. The statute may expressly or by necessary implication indicate that exclusivity is required. ${ }^{23}$ Alternatively, the subject matter of the statute may reflect a need for exclusive federal supervision or national uniformity. ${ }^{2 \pm}$ Finally, the federal scheme may be so pervasive or comprehensive that it precludes the coexistence of state regulation. ${ }^{25}$ If the federal policy or law is exclusive, no further inquiry is made: necessarily the state policy is voided. ${ }^{20}$

If the federal policy is found not to be exclusive, however, the court proceeds to the third step. Here the judge must first ascertain the substance and scope of the policy intended by Congress, ${ }^{27}$ and then determine whether the state program "stands as an obstacle to the accomplishment and execution of the full purposes and objectives of Congress."28 The state policy will be voided in so far as it blocks the effectiveness of the federal policy. Where performance of both standards is impossible, the state standard must give way. ${ }^{20}$ Even if legitimate state interests compel a more stringent policy, the state regulation may stand only to the extent that the federal policy will not be defeated. ${ }^{30}$

A comparison of the cases and close reading within single decisions indicate the importance of the third step: identifying the federal purpose and scope. ${ }^{31}$ The identification of the policy directs the court's

22. Id.

23. See Gibbons v. Ogden, 22 U.S. (9 Wheat.) 1 (1824); Hines v. Davidowitz, 312 U.S. 52 (1941).

24. Burbank v. Lockheed Air Terminal, Inc., 411 U.S. 624 (1973) (noise regulation by the CAB); Perez v. Campbell, 402 U.S. 637 (1971) (discharge from bankruptcy); Rice v. Santa Fe Elevator Corp., 331 U.S. 218, 230 (1947); Hines v. Davidowitz, 312 U.S. 52, 67 (1941). But see Kewanee Oil Co. v. Bicron Corp., 416 U.S. 470 (1974) (patent law does not preempt state trade secrets laws); Goldstein v. California, 412 U.S. 546 (1973) (copyright laws do not preempt state laws punishing "record piracy").

25. Local 496, Letter Carriers v. Austin, 418 U.S. 264 (1974); San Diego Bldg. Trades Council v. Garmon, 359 U.S. 236 (1959) (labor laws); Northern States Power Co. v. Minnesota, 447 F.2d 1143 (8th Cir. 1971), aff'd without opinion, 405 U.S. 1035 (1972)

(Atomic Energy Comm'n regulations).

26. See, e.g., Rice v. Santa Fe Elevator Corp., 331 U.S. 218, 236 (1947).

27. See Rice v. Santa Fe Elevator Corp., 33I U.S. 218, 230 (1947).

28. Florida Lime \& Avocado Growers, Inc. v. Paul, 373 U.S. 132, 141 (1962), quoting

Hines v. Davidowitz, 312 U.S. 52, 67 (1941).

29. See Florida Lime \& Avocado Growers, Inc. v. Paul, 373 U.S. 132, 142 (1962).

30. See Huron Portland Cement Co. v. Detroit, 362 U.S. 440,445 (1960) (city regulation protecting air quality not preempted by the Federal Boiler Inspection Act and not a burden on interstate commerce).

31. Compare Huron Portland Cement Co. v. Detroit, 362 U.S. 440 (1960), and Florida Lime \& Avocado Growers, Inc. v. Paul, 373 U.S. 132 (1962), with Rice v. Santa Fe Elevator Corp., 331 U.S. 218 (1947).

For an analysis of these problems from another perspective in relation to Florida Lime

\& Avocado Growers, see Deutsch, Precedent and Adjudication, 83 Yal. L.J. 1553 (1974). 
inquiry to the potential conflicts between the federal policy and the effects of the state program.

\section{A Preemption Analysis of the Federal Antitrust Laws}

The Parker defense raises the issue of the relationship between state and federal power. The federal antitrust laws have been interpreted as establishing a paramount national policy in favor of competition..$^{32}$ Yet Parker allows state intervention which seemingly conflicts with that policy. A preemption analysis applied to the antitrust laws provides a framework for resolving the apparent anomaly.

The initial step in this analysis is to decide if a conflict may exist between the state and the federal regulation. To do this, the court must determine: first, whether the state is involved and, if so, the field of operation of the state program; and, second, whether the federal antitrust laws operate in the same field. The presence of state involvement, though ultimately a legal conclusion, is essentially a factual issue to be determined by the court in each case upon proof or judicial notice. ${ }^{33}$ Various state programs-including the regulation of utility rates, ${ }^{34}$ insurance premiums, ${ }^{35}$ agricultural production ${ }^{36}$ and fees charged by professionals ${ }^{37}$-operate to affect the prices paid by consumers for goods and services, and are thus potential antitrust violations. As a matter of statutory construction, the federal antitrust laws, although broad in scope, will apply to the activity only where the alleged restraint has significant effects on interstate commerce. ${ }^{38}$

32. See United States v. Philadelphia Nat'l Bank, 374 U.S. 321, 372 (1963); Northern Pac. Ry. v. United States, 356 U.S. 1, 4 (1958); United States v. Yellow Cab Co., 332 U.S. 218 (1947); United States v. Frankfort Distilleries, Inc., 324 U.S. 293 (1945).

33. See, e.g., Washington Gas Light Co. v. Virginia Elec. \&. Power Co., 438 F.2d 248, 252 (4th Cir. 1971) (silence of a state regulatory agency in not citing a plan as a violation of its regulations interpreted as approval, thereby establishing state involvement). This factual finding may vary from case to case, despite similar types of state regulation. Compare Washington Gas Light Co. v. Virginia Elec. \& Power Co., supra (agency approval by means of silent acquiescence is sufficient state action to allow a Parker defense), with International Tel. \& Tel. Corp. v. General Tel. \& Electronics Corp., 351 F. Supp. 1153,1202 (D. Hawaii 1972) (specific approval by local utility commissions of common ownership of both manufacturing and "distributing" arms of telephone service not sufficient state action).

34. See, e.g., Gaslight Co. v. Georgia Power Co., 440 F.2d 1135 (5th Cir. 1971), cert. denied, 404 U.S. 1062 (1972); Washington Gas Light Co. v. Virginia Elec. \& Power Co., 438 F.2d 248 (4th Cir. 1971).

35. See, e.g., Travelers Ins. Co. v. Blue Cross of W. Pa., 298 F. Supp. 1109 (W.D. Pa. 1969).

36. Parker v. Brown, 317 U.S. 341 (1943).

37. Goldfarb v. Virginia State Bar, 497 F.2d 1 (4th Cir. 1974), cert. granted, 95 S. Ct. 223 (1974); United States v. Oregon State Bar, 43 U.S.L.W. 2234 (D. Ore. Dec. 10, 1974); United States v. National Soc'y of Professional Eng'rs, 43 U.S.L.W. 2269 (D. Colo. Jan. 7, 1975).

38. The issue of the effect of the restraint on interstate commerce is a question of fact. See United States v. Arnold, Schwinn \& Co., 388 U.S. 365 (1967); White Motor Co. v. United States, 372 U.S. 253 (1963). As a matter of statutory interpretation, the antitrust 
Where a possible conflict is posed by the operation in the same field of both the state program and the antitrust laws, the court must proceed to the next step in the preemption analysis and determine whether the federal interest is exclusive.

The antitrust laws are not an exclusive system of regulation to the extent of completely forbidding any state regulation. Neither the legislative history of the Sherman Act nor the opinions of the Court require the Sherman Act to be exclusive of all other regulation. ${ }^{39}$ For example, states may pass their own antitrust laws. ${ }^{40}$ Rather, the antitrust laws are an interstitial system, an attempt to regulate competition as one aspect of economic life. ${ }^{41}$ The limitation on state regulation, therefore, is that of inconsistency of result, so that the state activity will be invalid under the Supremacy Clause only if it interferes with the federal policy. ${ }^{42}$

As evolved through judicial interpretation, the federal antitrust laws promote three general policies: to preserve competition and thus maintain allocative efficiency; to preserve competition and thus protect consumers by ensuring adequate quality at a fair price; and to preserve small competitors, both as a noneconomic social goal and as a means of approximating the "perfect market." 43 All of these goals may be served so long as the market is functioning properly. However, in a variety of situations the market may break down and make simultaneous achievement of all the goals impossible, e.g., where poor economic conditions temporarily prevent competition from creating sufficient demand at an adequate price; ${ }^{44}$ where there is a natural

laws will not apply to activity that is local in nature. See, e.g., Gulf Oil Corp. v. Copp Paving Co., 95 S. Ct. 392 (1974) (Robinson-Patman Act does not apply to certain suppliers of paving material because they were not "in [interstate] commerce" within the meaning of the Act). In fact, Parker-type regulatory activity may often be intrastate in its effects. See Hecht v. Pro-Football, Inc., 444 F.2d 931 (D.C. Cir. 1971), cert. denied, 404 U.S. 1047 (1972). In addition to being attacked under the Sherman Act, a state regulation that has interstate effects may also be challenged as a burden on interstate commerce. See Pikc v. Bruce Church, Inc., 397 U.S. 137 (1970).

39. See P. AREEDA, ANTITRUST ANAI.YSIs 115 (2d ed. 1974); Note, The Commerce Clause and State Antitrust Regulation, 61 Colum. L. REv. 1469 (1961); Mosk, State Antitrust Enforcement and Coordination with Federal Enforcement, 21 A.B.A. ANTITRUST SECTION REP. 358, 36 ' (1962).

40. See Waters-Pierce Oil Co. v. Texas, 212 U.S. 86 (1909); Peoples Sav. Bank v. Stoddard, 359 Mich. 297, 102 N.W.2d 777 (1960); Texas v. Southeast Texas Chap., Nat'l Elec. Contractors Ass'n, 358 S.W.2d 711 (Tex. Civ. App. 1962); Alfred M. Lewis, Inc. v. Local 542, Warehousemen, 163 Cal. App. 2d 771, 330 P.2d 53 (1968); P. AREEDA, supra note 39 , at 115 .

41. See, e.g., United States v. Line Material Co., 333 U.S. 287, 310 (1948); Hiland Dairy, Inc. v. Kroger Co., 402 F.2d 968 (8th Cir. 1968), cert. denied, 395 U.S. 961 (1969).

42. See generally Flood v. Kuhn, 443 F.2d 264 (2d Cir. 1971), aff'd, 407 U.S. 258 (1972); note 28 supra.

43. See Bork, Bowman, Blake \& Jones, Goals of Antitrust-A Dialogue on Policy, 65 Colum. L. REv. 363 (1965); United States v. Von's Grocery Co., 384 U.S. 270, 274 (1960).

44. E.g., Parker v. Brown, 317 U.S. 341 (1943). The result in this situation is to drive out small competitors who are unable to survive the crisis. In rare circumstances, the 
monopoly, so that the service can be profitably provided by a private party only if competition is controlled; 45 or where high barriers to entry or limit pricing by a dominant market firm prevent viable competition..$^{4 B}$

The federal courts are generally responsible for determining whether the policies of the federal antitrust laws are being served. In those circumstances, however, where the three general policies cannot all be met, a choice among them must be made. The federal judiciary has neither guidance from Congress nor any particular expertise to determine which of the several goals is most important in a particular situation.

The federal system contemplates states as sovereigns within their spheres of authority, and comity must be shown to them. ${ }^{47}$ That does not mean that all state programs must be recognized, but rather that the federal courts should be reluctant to void a reasonable state policy as inconsistent with a superior federal interest. The federal policy which is thought applicable must be clearly endangered by the state act. Such is the teaching of preemption. Where the various goals of the federal antitrust laws cannot be simultaneously achieved, so that a choice among them is necessary, the decision by a state to effectuate one of the recognized federal policies should not be considered inconsistent with paramount federal law. Therefore, such state activity is exempt because it is in fact not contrary to the underlying federal policy. Moreover, the action of a state in such a situation provides

Court has recognized that this economic situation may justify private action which would otherwise be violative of the Sherman Act. This explains the seemingly inconsistent results in Appalachian Coals and Socony-Vacuum. Compare Appalachian Coals, Inc. v. United States, 288 U.S. 344 (1933), with United States v. Socony-Vacuum Oil, 310 U.S. 150 (1940). In each case, the economic situation was poor, with high production causing low prices. In each case, producers attempted to band together to reduce output and maintain prices. But Appalachian involved a program designed to help small producers who would otherwise be driven from the market, leaving it to a few large producers. Socony was a program designed by large producers to maintain a price which was being undercut by small producers. Thus, where small competitors were helped to survive in a period of economic difficulty, the Court upheld the program despite its effects on price and output; but where the program protected large sellers from price competition by small sellers, and the economic situation would not have caused the demise of the small competitors, the Court invalidated the anticompetitive program.

45. E.g., Gaslight Co. v. Georgia Power Co., 440 F.2d 1135 (5th Cir. 1971), cert. denied, 404 U.S. 1062 (1972); Washington Gas Light Co. v. Virginia Elec. \& Power Co., 438 F.2d 248 (4th Cir. 1971); International Tel. \& Tel. Corp. v. General Tel. \& Electronics Corp., $351 \mathrm{~F}$. Supp. 1153 (D. Hawaii 1972). In this situation, where the entry of competitors is severely limited, the only restraints on the price of the service to the consumer are those provided by state regulation and the demand curve of the product.

46. See Note, Telex v. IBM: Monopoly Pricing under Section 2 of the Sherman Act, 84 YALE L.J. 558 (1975).

47. The states are sovereign save only as Congress may constitutionally subtract from their authority. 317 U.S. at 351 . The Tenth Amendment is, at the very least, a declaration that reserved powers do exist in the states. U.S. CoNsT. amend. X. See United States v. Darby, 312 U.S. 100 (1941). 
the opinion of a decisionmaker neutral between the consumer and the competitors as to which interest will be protected. ${ }^{48}$ Such a policy determination is legislative in character and better left to those responsible for "political" judgments. ${ }^{49}$

The federal courts are still able to prevent the abuse of state power, for they must pass on whether there in fact exists a situation where all of the antitrust policies cannot be fulfilled. However, where its decision does not result in an undue burden on interstate commerce, the state is allowed to act because the choice is better made there.

The question of whether the state is involved, and the extent of the state involvement, were partial approaches to this question: whether in fact a neutral, sovereign state had made a choice among the federal policies. But they ignored the issue of whether the situation was one in which such a choice was necessary. The analysis under the preemption doctrine enables the court to face both issues squarely, and still leaves to the states an appropriate authority to regulate economic affairs.

It thus becomes apparent that in applying the preemption analysis, the court must look beyond the face of the statutes involved to the market characteristics in the particular situation. Only by examining the actual circumstances can the court determine whether the state policy may stand, because it in fact reflects a political choice among conflicting federal antitrust policies.

48. There is of course an underlying assumption here that state governments are not controlled by any single special interest, but that the powers of the voters and the competing voices of various special interests create an approximation of a neutral decision in the public interest.

49. See Baker v. Carr, 369 U.S. 186, 214 (1962); cf. Orlando v. Laird, 443 F.2d 1039, 1042-43 (2d Cir.), cert. denied, 404 U.S. 869 (1971).

Where state activity is found to be preempted by the Sherman Act, and thus subject to its proscriptions, other issues beyond the scope of this Note arise. Not all state activity subject to the antitrust laws would necessarily be voided thereby; rather, the activity would be subject to the rule of reason. See note 2 supra. In making determinations about the reasonableness of state activity, courts should not be bound to come to the same results that they would reach if private parties had acted in a similar manner. The antitrust laws are "common law" in nature; that is, Congress has set only general guidelines, allowing the policy to be filled in by the courts on a case-by-case basis. See United States v. Paxker-Rust-Proof Co., 61 F. Supp, 805, 812 (E.D. Mich. 1945); P. AREEDA, supra note 39 , at 4 . One factor to be considered in applying the rule of reason in this area is that a sovereign state rather than a private party has engaged in the conduct. Professor S. Paul Posner has developed a partial rationale for treating a state as subject to the antitrust laws but judging its acts by a more lenient standard than private action. Posner, supra note 18 , at 705-07, 712, 721-27.

Any analysis of state activity under the rule of reason, whether treating it more leniently or in the same manner as private conduct, must make the determination of whether the state activity is reasonable both in general and as applied in the particular situation. Indeed, such decisions are already made under the existing Parker doctrine, for state activity has been held subject to the federal antitrust laws where courts have found crror in either the agency's judgment or the information presented to it. See United States v. Pacific Southwest Airlines, 358 F. Supp. 1224 (C.D. Cal.), appeal dismissed pursuant to Rule 60, 414 U.S. 801 (1973); Woods Exploration \& Prod. Co. v. Aluminum Co. of Am., 438 F.2d 1286 (5th Cir. 1971), cert. denied, 404 U.S. 1047 (1972). 


\section{The Parker Defense and the Doctrine of Preemption}

The traditional interpretation of Parker is framed in jurisdictional terms. Under this approach, Parker is read to hold, as a matter of statutory construction, that a state and its officials are not within the intended reach of the Sherman Act. ${ }^{50}$ Because the suit in Parker was brought against the state to enjoin enforcement of its agricultural proration program, such a jurisdictional decision would have been sufficient to dispose of the case. ${ }^{51}$ However, the Court did not narrowly limit its analysis to the issue of whether a state was a "person" within the meaning of the federal statute. ${ }^{52}$ The Court also noted that it was not faced with a situation in which a state had authorized or participated in private conduct violative of the Sherman Act. ${ }^{53}$ If a state were not within the Act on jurisdictional grounds, the fact of joining a private conspiracy would be of no concern. ${ }^{54}$

In addition to these difficulties with the Court's opinion, the jurisdictional theory of Parker is unsatisfactory for other reasons. First, the Court in Parker failed to give any guidance as to the type of state activity or the degree of state involvement required to establish the defense, ${ }^{55}$ which may indicate that the Court did not perceive the issue in terms of "state action." 56 Moreover, because of this lack of guidance from the Court, the jurisdictional theory has resulted in considerable confusion and uncertainty in the case law. Some courts have upheld the defense even though the state was involved only to a limited extent. ${ }^{57}$ On the other hand, not all state action is held to

50. Slater, supra note 9 , at 73 .

51. It is also clear that Congress did not have state agencies in mind when it passed the Sherman Act. The era of government agencies was just beginning: the interstate Commerce Commission, the first of the federal regulatory agencies, was not founded until 1887, just three years prior to the passage of the Sherman Act. Instead, congressional attention was focused on the possibilities of domination of the economy by private business combinations. See 317 U.S. at 351.

52. Id. at 350-52.

53. Id. at 351-52.

54. Note the parallel between the suggestion in Parker that the state would lose its cxemption by joining a private conspiracy and decisions in other areas of the antitrust laws, holding that exempted persons become subject to the antitrust laws once they join conspiracies with nonexempt parties. See, e.g., Allen-Bradley Co. v. Local 3, IBEW, 325 U.S. 797 (1945); UMW v. Pennington, 381 U.S. 657 (1965); United States v. Borden Co., 308 U.S. 188, 204 (1939); Case-Swayne Co. v. Sunkist Growers, Inc., 389 U.S. 384 (1967).

However, such a parallel ultimately proves to be misleading. In the above cases, the cxempt party was clearly subject to the antitrust laws, except in so far as their organizational activities were specifically protected. See note 3 supra. The determination that a state is not a person within the meaning of the Sherman Act, however, would seem to remove states absolutely from the prohibition of the Act. It is unclear why joining a conspiracy would convert the state into a "person" within the meaning of the Act.

55. See Slater, supra note 9 , at $73-74$ n.13.

56. Where the Court has been concerned with such problems in other cases, it has given clearer definition than in Parker as to what action is required or exempted. See, e.g., Florida Lime \& Avocado Growers, Inc. v. Paul, 373 U.S. 132 (1963).

57. See, e.g., Washington Gas Light Co. v. Virginia Elec. \& Power Co., 438 F.2d 248 (4th Cir. 1971). 
be exempt, and the defense has been disallowed for activity that had clearly been approved by the state. ${ }^{.8}$ Finally, the "jurisdictional" antitrust exemption would apply only to the state or its officers, and would be inapplicable in suits against private parties. However, the lower federal courts have greatly expanded the Parker defense to include private persons involved in regulated industries, ${ }^{50}$ and this broader doctrine seems too well established to allow a return to such a narrow reading. ${ }^{00}$

These difficulties may be avoided if Parker is read in preemption terms. ${ }^{61}$ Parker arose during a time of severe economic crisis and overproduction. Without the agricultural proration program it could reasonably have been assumed that the low prices occasioned by the large raisin crop would have destroyed or seriously harmed a number of producers. $^{62}$ The proration program, by stabilizing the market and maintaining prices, was thus aimed at protecting the number of com-

58. See, e.g., Woods Exploration \& Prod. Co. v. Aluminum Co. of Am., 438 F.2d 1286 (5th Cir. 1971), cert. denied, 404 U.S. 1047 (1972); United States v. Pacific Southwest Airlines, 358 F. Supp. 1224 (C.D. Cal.), appeal dismissed pursuant to Rule 60, 414 U.S. 801 (1967). In each case the court disregarded the action of a state commission charged with regulating the industry in question.

59. See, e.g., Washington Gas Light Co. v. Virginia Elec. \& Power Co., 438 F.2d 248 (4th Cir. 1971); International Tel. \& Tel. Corp. v. General Tel. \& Electronics Corp., 351 F. Supp. 1153 (D. Hawaii 1972); Gaslight Co. v. Georgia Power Co., 440 F.2d 1135 (5th Cir. 1971), cert. denied, 404 U.S. 1062 (1972). This expansion may be explained as a reluctance on the part of courts to hold a business person liable under federal statutes for obeying state law. See note 73 infra.

60. See Posner, supra note 18, at 697; Slater, supra note 9, at 73, 78; Teply, supra note 18 , at 274.

61. Parker was argued in the Supreme Court as a preemption case. In the district court, plaintiff Brown had contended that the proration program was unconstitutional as a burden on interstate commerce. Brown v. Parker, 39 F. Supp. 895 (S.D. Cal. 194I). The case was appealed to the Supreme Court solely on this ground, but during oral argument several Justices raised the issue of conflicts with federal laws: the Sherman Act, the Agricultural Marketing Agreement Act of 1937, and the Fourteenth Amendment. Supplemental Brief for Appellee at 1, Parker v. Brown, 317 U.S. 341 (1943). The case was set for reargument, and supplementary briefs were filed addressing the Sherman Act issue. Supplemental Brief for Appellant at 35-67; Supplemental Brief for Appellee at 2-29. The Solicitor General argued in detail that the proration program had been preempted by the Sherman Act. Brief for United States as Amicus Curiae at 52-66. The parties also discussed the question of preemption, although not to the same extent as the Solicitor General. See Supplemental Brief for Appellants at 38-39, 47-48; Supplemental Brief for Appellee at 27-28, 55. Much of the Court's language in its Sherman Act analysis seems clearly to be in response to these preemption arguments. 317 U.S. at $350-52$.

62. In Parker, the state agricultural proration program was consistent with and in fact supported by the federal Agricultural Adjustment Marketing Act. 317 U.S. at 352-59. Some commentators have therefore explained Parker on the basis that Congress had itself implied an exemption by creating a federal policy with similar effects. See, e.g., P. AREEDA, supra note 39, at 57; Slater, supra note 9, at 86 . However, it is questionable that the intention of Congress in passing the Adjustment Act was to create an antitrust exemption for state programs. Moreover, such an explanation does not touch upon the Court's broad language in its Sherman Act analysis, which has been read to apply to many situations where there was no comparable federal policy in support of the state regulation. Whatever value such an explanation has for Parker as an individual case, it has little, if any, value for explaining the Parker doctrine's continued vitality under other circumstances. See id. at 87 . 
petitors in the market. This policy of preserving viable competitors is a legitimate goal under the Sherman Act. ${ }^{63}$ However, if the state had merely declared illegal action to be legal, or if the state had joined a private agreement to restrain trade, it would not have been furthering a Sherman Act policy and could have been held in violation of the act. ${ }^{04}$

The cases after Parker may also be analyzed in preemption terms. Utility regulation cases are a prime example. ${ }^{65} \mathrm{~A}$ public utility generally operates in a field where competition would not result in adequate service at a return sufficient to support more than one seller. ${ }^{60}$ The public utility is thus a clear example of a "natural monopoly." 67 The state, usually by means of an administrative agency or commission, undertakes to control the monopoly and regulate its prices. This regulation furthers the Sherman Act policies of preserving allocative efficiency and ensuring fair prices for consumers. ${ }^{68}$ The state enforces a price close to the monopoly's costs while allowing a reasonable return on capital, thus minimizing resource misallocation due to monopoly profits and protecting consumers by maintaining the service at lower prices.

Of course, a state may not be able to further every goal of the antitrust laws at the same time. Thus, protecting the number of competitors, as in Parker, may not result in the lowest market price. ${ }^{60}$ Since the Sherman Act recognizes several goals, the promotion by the state of any one of them should be sufficient where every goal cannot be simultaneously achieved. Where, however, the state cannot justify its program by any of the antitrust policies, the state regulation should not establish a Parker defense. ${ }^{70}$

63. United States v. Von's Grocery Co., 384 U.S. 270 (1966) (Clayton Act); United States v. Aluminum Co. of Am., 148 F.2d 416, 429 (2d Cir. 1945).

64. See Schwegmann Bros. v. Calvert Corp., 341 U.S. 384, 389 (1951).

65. See, e.g., Gaslight Co. v. Georgia Power Co., 440 F.2d 1135 (5th Cir. 1971), cert. denied, 404 U.S. 1062 (1972); Washington Gas Light Co. v. Virginia Elec. \& Power Co., 438 F.2d 248 (4th Cir. 1971); International Tel. \& Tel. Corp. v. General Tel. \& Electronics Corp., 351 F. Supp. 1153 (D. Hawaii 1972).

66. See C. Kaysen \& D. Turner, Antitrust Policy 191 (1959). See generally Otter Tail

Power Co. v. United States, 410 U.S. 366, 387 (1973) (Stewart, J., dissenting).

67. C. KAYSEN \& D. TURNER, supra note 66, at 191 .

68. See Mandeville Island Farms, Inc. v. American Crystal Sugar Co., 334 U.S. 219, 236 (1948). See generally Ethyl Gasoline Corp. v. United States, 309 U.S. 436, 458 (1940).

69. See, e.g., Parker v. Brown, 317 U.S. 341 (1943); E.W. Wiggins Airways, Inc. v. Massachusetts Port Auth., 362 F.2d 52 (1st Cir.), cert. denied, 385 U.S. 947 (1966).

70. See, e.g., United States v. Pacific Southwest Airlines, 358 F. Supp. 1224 (C.D. Cal.), cert. dismissed, 414 U.S. 801 (1973). In this case, state agency approval of the merger of two intrastate carriers was held by the court to be insufficient to establish a Parker defense. Although the court applied the "state action" theory of Parker, the result is consistent with preemption analysis. No competitors were being saved by the merger, and consumers would have suffered a cutback in services. Nor was it clear that the 
Analyzing the Parker defense in terms of preemption has several advantages. It provides an analytical structure with which courts are already familiar, instead of attempting, without clear guidance, to define the required level of "valid government action." It also gives the proper weight to the paramount federal interest. Where the market is functioning, a state policy which prevents competition should not, under the Supremacy Clause, be exempt from the federal antitrust laws, no matter what the level of state involvement. On the other hand, where the market mechanism has broken down and the state responds in a way compatible with the underlying antitrust policies, the preemption analysis permits the federal courts to defer to the expertise of state agencies and to recognize the legitimate economic interests which the state is seeking to protect. ${ }^{71}$ Finally, because it establishes a clear and consistent theoretical basis for the Parker doctrine, the preemption analysis has the advantage of providing certainty and predictability in the law..$^{22}$ This will improve the quality of judicial decisions, limit the discretion of the judges, and make lower court opinions more amenable to meaningful appellate review. It will also allow business persons to plan and conduct their affairs in an informed and intelligent manner. ${ }^{73}$

merger would prevent the misallocation of resources, since prices were already regulated by the state agency. Since the merger thus did not effectuate any policy of the federal antitrust laws, the action of the state agency was preempted and therefore did not justify a Parker defense.

71. See Posner, supra note 18 , at $697,712,738$.

72. The Court's decisions in Eastern R.R. Presidents' Conf. v. Noerr Motor Freight, Inc., 365 U.S. 127 (1961), and UMW v. Pennington, 381 U.S. 657 (1965), are not inconsistent with the suggested preemption analysis, even though some state action would be subject to the federal antitrust laws. The Noerr-Pennington doctrine protects the right under the First Amendment to petition for redress of grievances and to seek to affect legislative or agency action. The doctrine has never been held to protect the subsequent legislation or decision from scrutiny under the Commerce Clause, the antitrust laws, or other statutory or constitutional provision. See Simmons \& Fornaciari, supra note 18, at 98. On the Noerr-Pennington doctrine, see California Motor Transport v. Trucking Unlimited, 404 U.S. 508 (1972) (First Amendment protection of access to administrative agencies does not include mere shams to deter and harass competition); Sacramento Bottling Co. v. Teamsters Local 150, 440 F.2d 1096 (9th Cir.), cert. denied, 404 U.S. 826 (1971); George R. Whitten, Jr., Inc. v. Paddock Pool Builders, Inc., 424 F.2d 25 (lst Cir.), cert. denied, 400 U.S. 850 (1970) (restricting the Noerr-Pennington rule to access to policymakers and refusing to allow immunity for threats and coercion).

73. A business person faced with the conflicting demands of state and federal law is in a difficult position. However, this problem is not a new one created by the preemption analysis, but rather already exists under the presently prevailing interpretation of Parker. Indeed, the problem is more acute now because of the failure to provide clear standards for applying the Parker defense, and the fact that the failure to make out the defense results in the imposition of liability. See, e.g., Woods Exploration \& Prod. Co. v. Aluminum Co. of Am., 438 F.2d 1286 (5th Cir. 1971), cert. denied, 404 U.S. 1047 (1972).

The preemption analysis will better enable the business person to judge whether the state regulation is valid under the federal antitrust laws. Moreover, good faith reliance on the state regulation need not result in the imposition of treble damages. See Posner, supra note 18, at 735-39. Absent a defense of good faith reliance, the severe sanction of treble damages under federal law might well force the business person to violate the 


\section{Conclusion}

This Note has examined the shortcomings of the prevailing "state action" interpretation of the Parker doctrine. Such a theory allows states to approve activities violative of the federal antitrust laws without according sufficient importance to those interests protected by the antitrust laws. Moreover, there are no standards by which to determine the types or levels of state involvement necessary to establish a Parker defense.

These shortcomings may be avoided by examining Parker in terms of a preemption analysis. The preemption analysis is based on the recognition that, while in most situations a competitive market will serve the federal interests of protecting consumers, preserving competitors and efficiently allocating resources, there are some circumstances where not all of these goals can be achieved. In those instances, it is legitimate for the state to choose which goal will be fostered, even at the expense of competition. Such an analysis avoids the analytical difficulties presented by the state action theory of Parker, allows state regulation of appropriate economic areas, and ensures that the interests embodied in the federal antitrust laws will be protected. It is time for the Court to take a case presenting these issues and decide it clearly, so that lower federal courts, states and the business community will be guided. ${ }^{74}$

state statute or order. However, this seems fundamentally unfair, especially since state penalties are likely to be immediate and certain. The violation of state law would also interfere with the need for the smooth and uninterrupted operation of industries regulated by the state, particularly public utilities. Therefore, a defense of good faith reliance should be allowed. Damages would be imposed only for acts done after a judicial decision provided notice to the parties and to the state that the regulation was invalid. Id. at 728-32. Such an approach has some support in antitrust case law. See CaseSwayne Co. v. Sunkist Growers, Inc., 389 U.S. 384, 396-400 (1967) (Harlan, J., concurring and dissenting) (although Sunkist's exemption from the antitrust laws was found by the Court to be no longer applicable, Harlan urged that only future liability should be imposed because of the prior judicial approval of the Sunkist plan). Nor is criminal liability a real danger. Criminal prosecutions under the Sherman Act are rare, and the imposition of criminal penalties requires a "willful" violation. See REPORT, supra note 2, at 350; P. AREEDA, supra note 39, at 49-55. Good faith reliance on the state regulation should not and probably would not result in criminal sanctions. But here, as in the Noerr-Pennington area, see note 72 supra, bad faith or sham reliance on the state regulation in order to create unreasonable restraints of trade should be punishable.

74. The issue was argued to the court in Goldfarb v. Virginia State Bar, 497 F.2d 1 (4th Cir.), cert. granted, $95 \mathrm{~S}$. Ct. 223 (1974). The issue may arise in a consolidated case dealing with the applicability of the antitrust laws to certain agricultural marketing cooperatives. See United States v. National Broiler Mktg. Ass'n, Civil No. 18173 (N.D. Ga., filed April 16, 1973). The consolidated action is presently in the pretrial stage, and includes several states as well as the Department of Justice. 


\section{Yale Studies in}

World

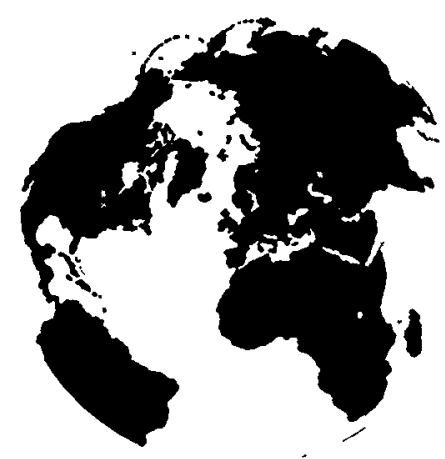

Public

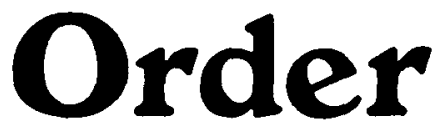

\section{VOLUME 1}

Number 1

1974

The New Haven School of International Law: An Invitation to a Policy-Oriented Jurisprudence

The Developing International Law on Gathering and Sharing Security Intelligence

Humanitarian Intervention Under Contemporary International Law: A Policy-Oriented Approach

An International Structure for Implementation of the 1949 Geneva Conventions: Needs and Function Analysis

$\$ 5.00$ per issue - United States

$\$ 6.00$ per issue - Canada and Mexico

$\$ 7.00$ per issue - Foreign Countries

Please address all inquiries to:

YALE STUDIES IN WORLD PUBLIC ORDER

Box 2102 - Yale Station

New Haven, Connecticut 06520 